Int. J. Dev. Biol. 48: 903-911 (2004)

doi: $10.1387 / \mathrm{ijdb} .041860 \mathrm{jz}$

\title{
Corneal development associated with eyelid opening
}

\author{
JAMES D. ZIESKE* \\ Schepens Eye Research Institute and Department of Ophthalmology, Harvard Medical School, Boston, Massachusetts, USA
}

\begin{abstract}
The development of the cornea as a tissue initiates as early as five weeks in the human embryo. This development continues gradually until the time of eyelid opening, which is associated with major developmental changes. These events, most easily observed in rodents, which are born with closed eyelids, include alterations in the rate of cell proliferation in the epithelium, stroma and endothelium; differentiation of the epithelium; appearance of a tear film and tear-film-associated proteins; and swelling and thinning of the stroma. Eyelid opening is also associated with numerous alterations in gene expression. These events are the subject of this review. Readers are directed to the article by Wolosin et al., also in this volume, for an in-depth discussion of early corneal development.
\end{abstract}

KEY WORDS: cornea, eyelid, corneal development, corneal epithelium, stroma

\section{Corneal structure and function}

The adult cornea (Fig. 1) consists of a stratified non-keratinizing epithelial cell layer, a thick highly aligned collagenous stroma interspersed with keratocytes, and a single cell layered endothelium. The epithelium sits atop a basement membrane and the endothelial layer resides on a thickened basement membrane, termed Decemet's membrane. In addition, primates and some birds exhibit an acellular layer (approximately $10 \mu \mathrm{m}$ thick) beneath the epithelial basement membrane that is termed Bowman's layer or membrane. This term is frequently misused to refer to the epithelial basement membrane. Through the combination of these various cell layers, the cornea performs three main functions: protection, transmittance of light, and refraction of light. Indeed, the cornea is the main lens of the eye providing $70-75 \%$ of the refractive power (Hogan etal., 1971; Jakobiec and Ozanics, 1982; Maurice, 1985).

\section{Corneal organogenesis}

Corneal organogenesis has been extensively reviewed in chicks by Hay (Hay, 1979) and in humans by Sevel and Isaacs (Sevel and Isaacs, 1988), and Barishak (Barishak, 2001). In brief, the vertebrate cornea begins its development as the ectoderm overlaying the lens. This primitive epithelium, two cells in thickness, is first apparent at about five weeks in the human embryo and is contiguous with the surface ectoderm. During the next oneto-two weeks in humans, the epithelium stratifies to three-to-four cell-layers thick, the lens completes its formation and detaches from the ectoderm, and the eyelids form and fuse. Almost immediately after the separation of the lens from the corneal epithelium, waves of neural crest cells migrate into the space between the lens and epithelium. These cells become the corneal endothelium and the stromal keratocytes. This migration of cells appears to be species specific. For example, in reptiles, birds, and primates, including humans, two waves are observed - first, endothelial cells then keratocytes. However, in rodents, cats, rabbits, and cattle, a single migration of cells, resulting in both cell types, is observed (Cintron et al., 1983). In the chick, the epithelial cells secrete a collagenous matrix (termed the primary stroma) prior to the influx of neural crest cells (Hay, 1979). This primary stroma is not observed in rabbits, mice, or primates (Cintron et al., 1983).

Following fusion of the eyelids, the primitive corneal epithelium decreases to two cell layers and remains constant until the time of eyelid opening (twenty-four weeks in humans). During the period of eyelid closure, the cornea gradually enlarges and matures. Upon eyelid opening, a number of developmental events occur that result in a mature cornea. These events form the basis of this review.

\section{Morphological changes associated with eyelid opening}

Eyelid opening appears to stimulate similar events in all species that undergo the process of eyelid fusion and subsequent opening.

Abbreviations used in this paper: D, Descemet's membrane; E, epithelium; EGF, epidermal growth factor; En, endothelium; Ep, corneal epithelium; LM, eyelid margin; $\mathrm{S}$ or St, stroma.

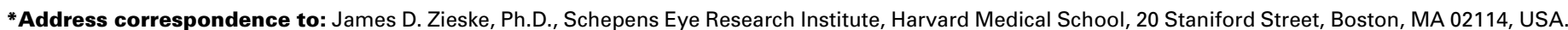
Fax: +1-617-912-0107. e-mail: zieske@vision.eri.harvard.edu.
} 


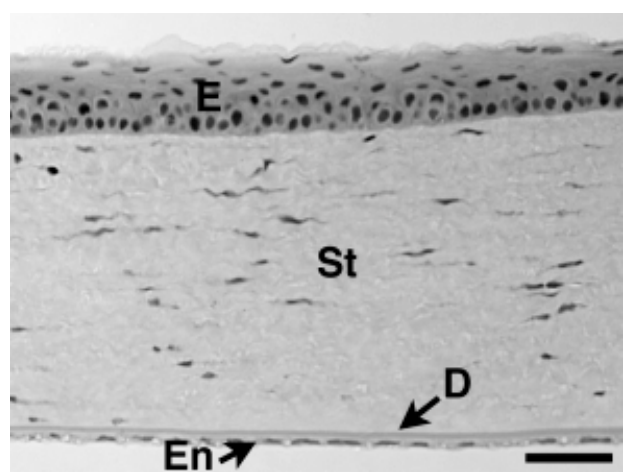

Fig. 1. Cross-section of the mature rat cornea. The epithelium (E) forms the anterior-most portion of the cornea and serves to protect the remainder of the cornea from fluid loss and pathogen penetration. The epithelium is adherent to a basement membrane. Subjacent to the epithelium is a thick stroma (St) consisting of numerous collagen lamellae organized in an orthogonal pattern. Interspersed between the lamellae are stromal fibroblasts, termed keratocytes. The organized pattern of the stroma provides strength and allows light to be transmitted with minimal distortion. Descemet's membrane (D) is a thickened basement membrane secreted by the endothelium (En). The endothelium is a single-cell layer that functions to pump water out of the stroma. Bar, $50 \mu \mathrm{m}$.

However, it is most easily studied in animals such as rodents, where eyelid opening occurs after birth.

\section{Corneal epithelium}

In the adult, the main function of the corneal epithelium is to serve as a protective barrier against fluid loss and pathogen penetration. As seen in Fig. 2, the corneal epithelium in rodents undergoes a remarkable level of differentiation and development that initiates just prior to eyelid opening (twelve-fourteen days-ofage in the rat) (Chung et al., 1992; Watanabe et al., 1993). Until seven days-of-age, only one or two layers of cells are present in the central cornea, the limbus, and the conjunctiva (Chung et al., 1992). At ten days-of-age, epithelial thickness increases to two-tothree layers in all areas. At two weeks-of-age, immediately following eyelid opening, four-to-five cell layers are present in central cornea. The thickness of the epithelium is nearly double that seen at ten days. The thickness continues to increase to five-to-six layers at three weeks, and by four weeks, the thickness reaches its adult level of six-to-seven cell layers. This increase in epithelial thickness has also been observed in developing mouse (Song et al., 2003) and human (Sevel and Isaacs, 1988) corneas. In mouse, the epithelium increases in thickness from $12.7 \mu \mathrm{m}$ at day one to $49.3 \mu \mathrm{m}$ at day thirty (Song et al., 2003). Similar changes have been observed in the limbal and conjunctival epithelia (Chung et al., 1992). Along with the change in the number of cell layers, a fundamental change in the shape of the basal cells has also been observed. Until ten days, the basal cells exhibited a flattened, ovoid appearance; however, immediately following eyelid opening, the basal cells became more rounded or cuboidal. At three weeks, the basal cells changed in shape from cuboidal to columnar (Chung et al., 1992). Interestingly, these changes only occurred in the central cornea, not in the limbal or conjunctival epithelium. Fundamental changes in the stratified layers of the epithelium also occur during this period. As cells leave the basal cell layer, they begin to flatten and appear to form more intracellular junctions, termed desmo- somes. Three-to-four layers of these cells (wing cells) are present in mature corneas. As the cells continue to stratify upwards, they continue to flatten and form the superficial cell layers. Tight junctions, a crucial component of the corneal epithelial barrier function, are present in these layers (Hogan etal., 1971). Unlike the epidermis, corneal epithelial cells do not lose their nucleus or undergo extensive keratinization. The process of terminal differentiation-leaving the basal cell layer, to sloughing from the superficial cell layer-takes approximately 7 days (Beebe and Masters, 1996; Hanna and O'Brien, 1960). Interestingly, it has recently been demonstrated (Norman et al., 2004) that there may be genes that are differentially expressed in each layer.

\section{Corneal stroma}

The stroma plays a major role in all the main functions of the mature cornea: protection, transmittance of light, and refraction of light. All of these functions are related to the highly organized extracellular matrix. This matrix is formed primarily by aligned bundles of collagen termed lamellae, which are stacked in an orthogonal pattern (Hogan et al., 1971).

As with the epithelium, the stroma also undergoes dramatic alter-
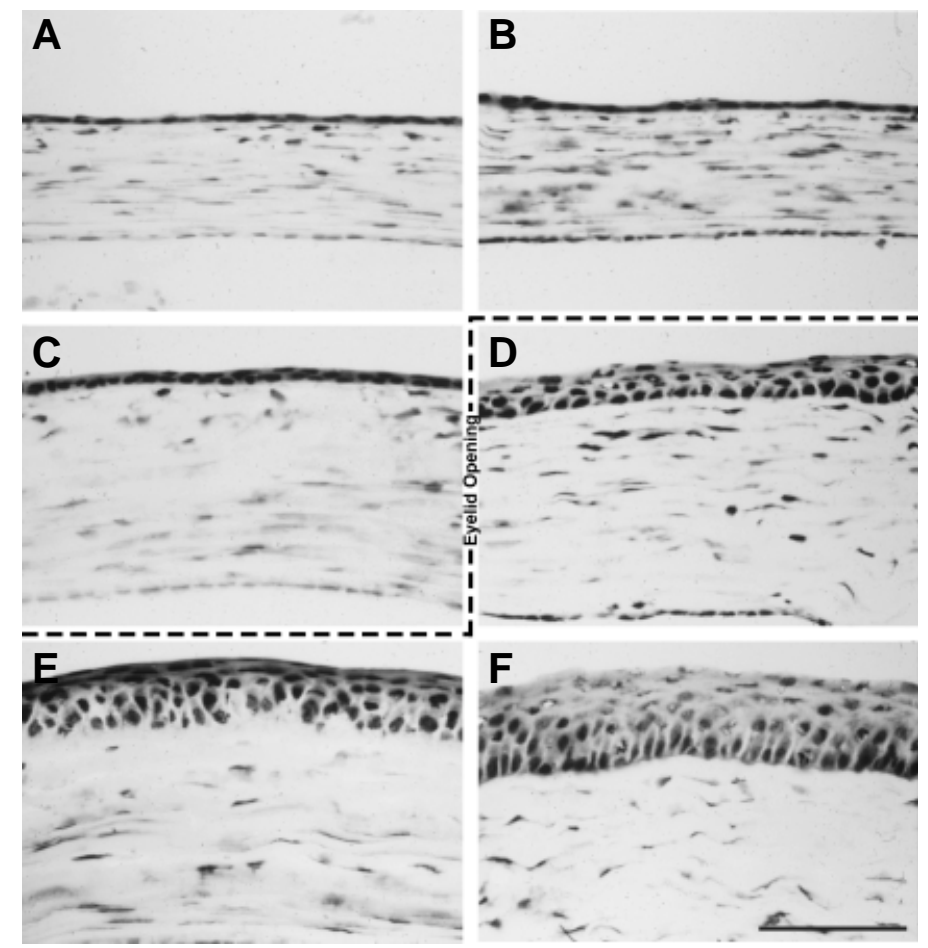

Fig. 2. Differentiation of central corneal epithelium associated with eyelid opening. At one (A) and seven (B) days-of-age, the central corneal epithelium is composed of one or two layers of cells. At ten days (C), just before eyelid opening, the number of cell layers increases to two or three. At two weeks (D), just after eyelid opening, four-to-five layers are observed. At three weeks (E), five-to-six layers are present, and at four weeks (F), the epithelium is indistinguishable from that of an adult. Note the shape change of the basal cells from flat ovoid to columnar that occurs as the epithelium differentiates. Also note the increase in stromal thickness and decrease in stromal cell density that occurs between seven and ten daysof-age. Bar, $50 \mu \mathrm{m}$. (Reproduced from Chung et al. (Chung et al., 1992), courtesy of Investigative Ophthalmology and Visual Science.) 
ations in thickness and cellularity at the time of eyelid opening. As seen in Fig. 2 B,C, stromal thickness increases significantly just prior to eyelid opening, and the density of cells appears to decrease. Song et al. (Song et al., 2003) examined this observation quantitatively in the developing mouse and found that the thickness of the stroma increased a remarkable $60 \%$ in the four days preceding eyelid opening. The same authors found that the density of stromal cells decreased by approximately $50 \%$ over the same time period. It is not known if the number of cells actually decreased or if the change in density was the result of the increase in stromal volume.

\section{Corneal endothelium}

The mature corneal endothelium functions to maintain the stroma in a relatively dehydrated state. This function depends on the presence of a barrier formed by focal tight junctions, which prevent fluid flow, and on a 'pumping' action provided by $\mathrm{Na}^{+} / \mathrm{K}^{+}$ATPase and $\mathrm{Mg}^{++}$-dependent bicarbonate enzymes present in the lateral membranes of the endothelial cells (Joyce, 2003).

In the developing corneal endothelium, morphological alterations associated with eyelid opening are less dramatic than those observed in the stroma or epithelium. The endothelium remains a monolayer throughout the entire development of the cornea and gradually thins with age. However, changes do occur during the time surrounding eyelid opening that likely have a profound effect on the endothelium becoming non-proliferative and initiating its barrier function (Bahn et al., 1986; Cintron et al., 1988; Haustein, 1983; Joyce et al., 2002; Murphy et al., 1984). Through electron microscopic studies, it has been demonstrated that, just before eyelid opening, intracellular spaces close and junctional complexes mature. In addition, Descemet's membrane has been found to be assembled into its mature form, during this period.

\section{Proliferative changes associated with eyelid opening}

Perhaps the most profound change to occur that is associated with eyelid opening is the dramatic alteration in levels of proliferation (Francesconi et al., 2000; Hanna and O'Brien, 1961; Joyce et al., 1998). As seen in Fig. 3A, at the time of birth, cell proliferation is present in the epithelium, stroma, and endothelium. Approximately $20 \%$ of the epithelial and stromal cells, and $12 \%$ of the endothelial cells, are actively progressing through the cell cycle (Fig. 3). By the time of eyelid opening, the number of cells actively proliferating in both the stroma and endothelium has decreased to nearly zero. This low level of proliferation will be maintained throughout the life of the cornea. In contrast, the level of proliferation increases noticeably in the corneal epithelium (Fig. 3) and peaks with almost $75 \%$ of the basal cells actively proliferating (Fig. 3B). By three weeks-of-age, the number of proliferating cells drops to that seen in the adult (Figs. 3C, 4). This burst of proliferation correlates well time-wise with the stratification of the epithelium (Fig. 2).

\section{Corneal epithelium}

During the time between birth and eyelid opening, the number of proliferating cells in the corneal epithelium increases almost four-fold (Fig. 4). One of the potential mediators of this increase is signaling through the epidermal growth factor (EGF) receptor (Zieske and Wasson, 1993). As seen in Fig. 5 A-D, EGF receptor
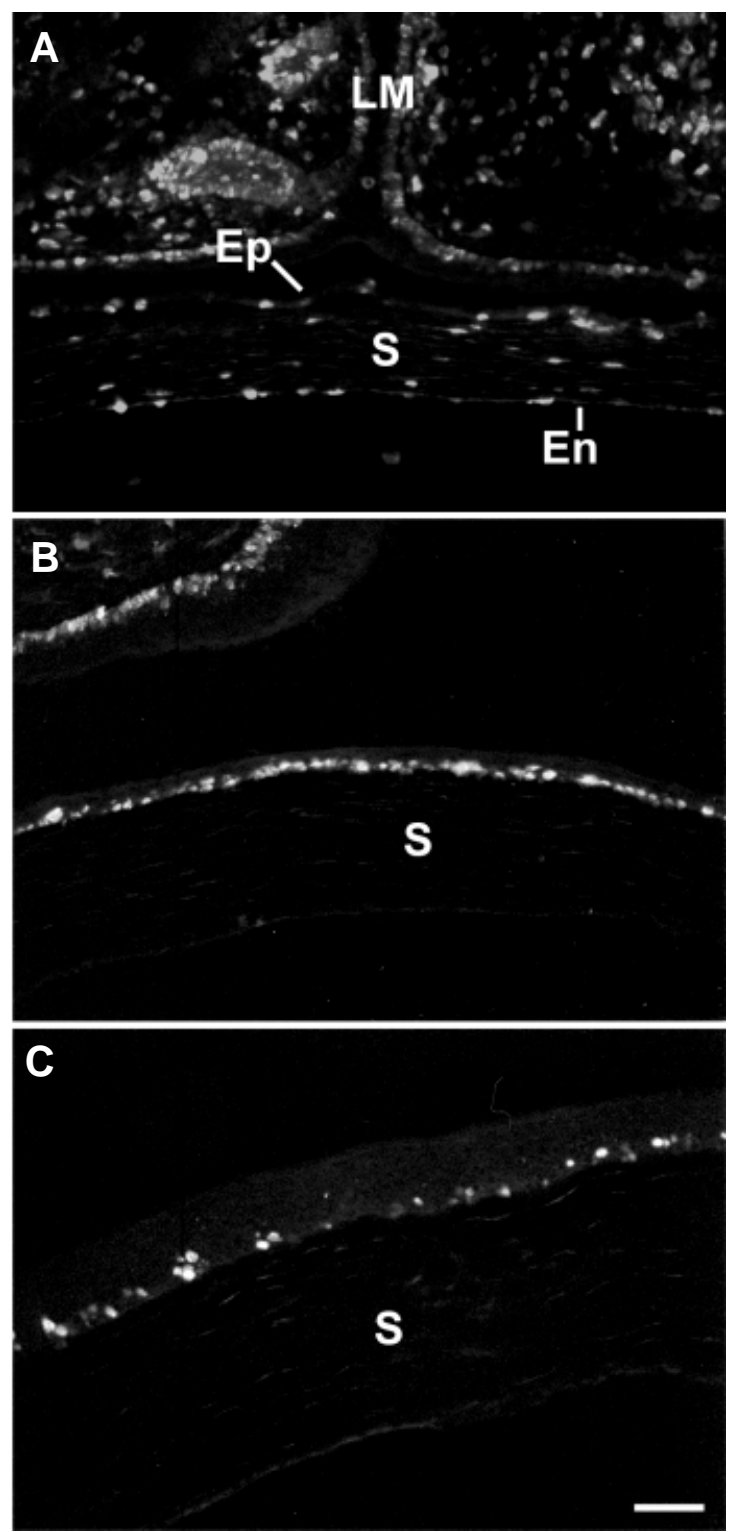

Fig. 3. Immunolocalization of Ki67 in developing rat cornea. Ki67 la marker of proliferating cells) was localized in central cornea of three-dayold (A), fifteen-day-old (B), and adult (C) rats. Ki67 was detected in the basal cell layer of corneal epithelium at all ages. Maximal localization of Ki67 in corneal epithelium correlated with eyelid opening $(B)$. Note the dramatic decrease in proliferating cells in the stroma and endothelium that occurs between three days after birth ( $A$ ) and one day after eyelid opening (B). $L M$, eyelid margin; Ep, corneal epithelium; S, stroma; En, endothelium. Bar, 50 $\mu \mathrm{m}$. (Reproduced from Francesconi et al. (Francesconi et al., 2000), courtesy of Investigative Ophthalmology and Visual Science.)

is present across the entire cornea at birth, and appears to increase at seven days-just prior to the increase in proliferative rate. This also correlates with the increase of EGF present in the plasma and presumably in the tear film (Beardmore and Richards, 1983; Thulesen et al., 1994; Tsutsumi et al., 1987). As the epithelium stratifies, the level of EGF receptor appears to decrease (Fig. 5 $E, F)$. This could potentially lead to the cessation of the proliferative burst preventing hyper-stratification of the epithelium. The concept 


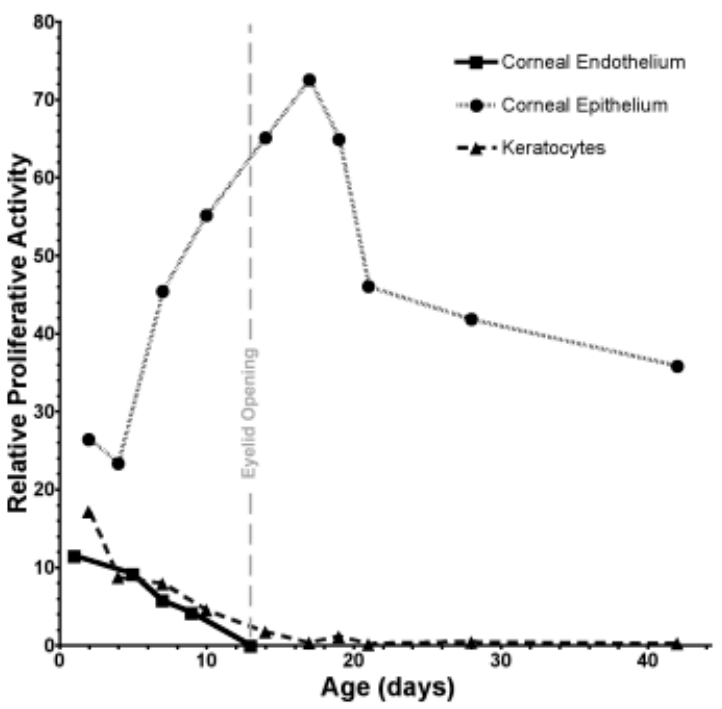

Fig. 4. Quantitation of proliferative cells during development. The number of Ki67-positive cells in corneal epithelium and stromal keratocytes, and the number of bromodeoxyuridine-positive cells in the endothelium were quantified, as described in Francesconi et al. (Francesconi et al., 2000) and Joyce et al. (Joyce et al., 1998), respectively. (Adapted from Francesconi et al. (Francesconi et al., 2000) and Joyce et al. (Joyce et al., 1998), courtesy of Investigative Ophthalmology and Visual Science.)

that signaling through the EGF receptor family is involved in epithelial stratification is supported by the findings of Xie et al. (Xie etal., 1999). They found in transgenic mice that were overexpressing the EGF receptor, ErbB2, that the mice were born with 5-7 layers of epithelial cells instead of the 2 layers seen in wild-type controls. Interestingly, the keratocytes also appeared to be hyperplastic, and the collagen lamellae were not arranged as precisely as seen in control mice.

Several proteins associated with cell cycle regulation have been examined during corneal development. Among these are the three members of the retinoblastoma family, as well as the E2F family of transcription factors (Francesconi et al., 2000). The retinoblastoma gene product $(\mathrm{pRb})$ is one of the key regulators of the cell cycle, and is normally hypophosphorylated in quiescent cells. When quiescent cells are stimulated to proliferate, $\mathrm{pRb}$ is phosphorylated, thereby disrupting the interaction between $p R b$ and E2F. Free E2F is then responsible for activating the transcription of genes necessary for DNA synthesis. In the developing corneal epithelium, $\mathrm{pRb}$ is present in the nuclei of all cells at all time points, and its expression and localization remain

Fig. 5. Immunolocalization of EGF receptor in developing rat corneas. EGF receptor is localized at high levels in rat corneal epithelium at one (A), four (B), and seven (C) days-ofage. (D) Phase-contrast micrograph of the area shown in (B). Note that only one or two layers of epithelial cells are present. As the epithelium begins to stratify, the level of EGF receptor appears to diminish (E); central cornea, ten days of age. (F) Phase-contrast micrograph of the area shown in (E). Note that a multilayered epithelium is present. Bars, $50 \mu \mathrm{m}$. (Reproduced from Zieske and Wasson (Zieske and Wasson, 1993), courtesy of Journal of Cell Science.) constant (Francesconi et al., 2000). We are aware of no evidence that phosphorylation of $\mathrm{pRb}$ is involved in corneal epithelial stratification. In contrast to $\mathrm{pRb}$, the expression and localization of the other two members of the retinoblastoma family, p107 and p130, are altered during corneal development.

At birth, p107 exhibits a nuclear localization in the basal cells across the cornea. During the period between birth and eyelid opening, p107 is increasingly localized in the cytoplasm, until little, if any, nuclear localization is observed. The significance of this change in localization is not clear. Interestingly, nuclear localization is maintained in the limbal basal cells.

The final member of the family, p130, differs from $\mathrm{pRb}$ and $\mathrm{p} 107$ in that it is phosphorylated in quiescent cells and its levels decrease in proliferating cells (Francesconi etal., 2000). Thus, its levels have been shown, in other systems, to be high in quiescent and terminally differentiated cells. In the rat corneal epithelium, p130 is not present at appreciable levels until stratification occurs. At approximately nine days-of-age, p130 is first observed in the nuclei of the non-basal, non-proliferating cells. Little, if any, p130 is localized in the proliferative basal epithelial cell layer. As the epithelium develops, the localization is confined to the terminally differentiated suprabasal cell layers. This pattern is maintained in the adult and is consistent with p130 playing a role in corneal epithelial differentiation (Francesconi et al., 2000).

Among the E2F family, only E2F1 localization changes during development (Francesconi et al., 2000). E2F1 is initially present at low levels until just before eyelid opening, when a nuclear localization is seen. This pattern is maintained in the adult and is consistent with E2F1 being a marker of differentiation; however, it is not clear what genes E2F1 may be regulating.

\section{Corneal stroma}

During the period between birth and eyelid opening in the rat, the number of proliferating cells decreases from approximately $20 \%$ of
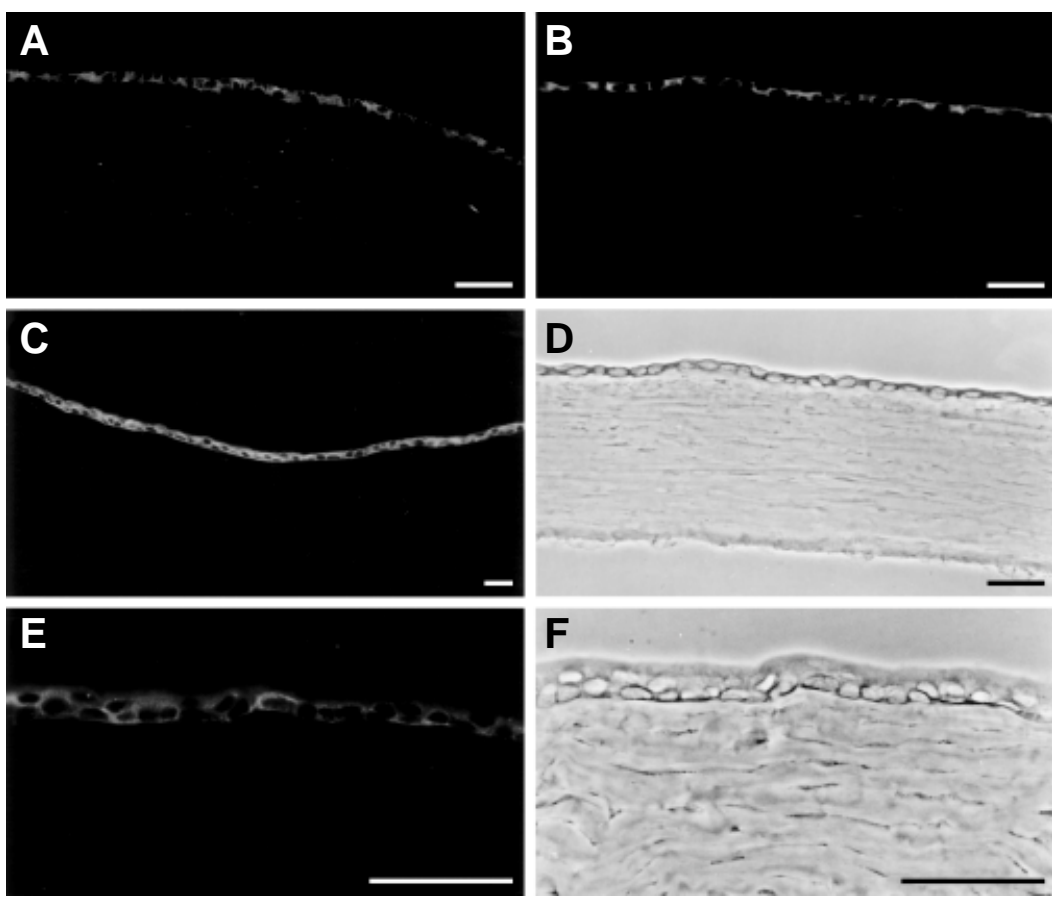
the total to essentially zero (Fig. 4). The mechanism for this decrease is unknown. Only a few studies have examined proteins associated with cell proliferation in corneal keratocytes during development. pRb is present in the nucleus of all stromal cells at all ages. p107 is present in low levels, until approximately three weeks-of-age and then decreases to undetectable levels. Most interestingly, p130 does not appear to be present until nine daysof-age, when a nuclear localization is observed. Its levels appear to increase as the proliferative rate of the keratocytes decreases and the cells become quiescent (Francesconi et al., 2000). In addition, it has been observed that, in the adult, the keratocytes express very little, if any, cyclins or cyclin-dependent kinase inhibitors (Joyce et al., 1996). This suggests that, during the time of eyelid opening, the keratocytes have exited the cell cycle and become quiescent G0 cells. The fact that the cells are in G0 rather than being terminally differentiated is supported by the findings that stromal keratocytes can be readily stimulated to proliferate in response to corneal wounding (Zieske et al., 2001).

\section{Corneal endothelium}

At birth, as many as $12 \%$ of corneal endothelial cells are actively undergoing cellular proliferation (Fig. 4). By the time of eyelid opening, the rate of proliferation drops to zero. This change in proliferative rate has been associated with the contact inhibition that occurs during the period prior to eyelid opening. Joyce and coworkers (Joyce et al., 2002) found that several proteins present in cell-cell junctions, including $\mathrm{ZO}-1$, connexin 43 , and $\mathrm{Na}^{+} / \mathrm{K}^{+}-$ ATPase, are expressed in corneal endothelium at birth, in the rat, but they do not localize into mature junctions until just prior to eyelid opening. Contact inhibition of cell proliferation appears to be mediated through the cell cycle inhibitor p27 KIP1. Several lines of evidence support this conclusion including: (1) p2 $7^{\mathrm{KIP} 1}$ levels are reduced when endothelial cells are stimulated by fibroblast growth factor-2 (Lee and Kay, 2003); (2) SV-40-transformed endothelial cells express less p27 KIP1 than untransformed cells (Schonthal et al., 1999); and (3) rat endothelial cells upregulate $\mathrm{p} 27^{\mathrm{KIP} 1}$ expression 20 fold when they become contact inhibited (Joyce et al., 2002).

In contrast to corneal keratocytes, corneal endothelial cells do not appear to enter the G0 phase of the cell cycle after eyelid opening; rather, they appear to be arrested in the G1 phase of the cycle. This finding is based on the observation that the endothelial cells continue to express G1-phase-associated proteins, such as cyclins $D$ and $E$, after eyelid opening and throughout adulthood (Joyce et al., 1996). Since p27 ${ }^{\mathrm{KIP} 1}$ is expressed in the adult cells, it appears that this inhibitor plays a major role in maintaining the cell cycle arrest (Joyce et al., 1998). It is an intriguing but unanswered question-why do the corneal keratocytes and endothelial cells use two separate mechanisms to achieve quiescence? The two cell types also vary widely in their ability to re-enter the cell cycle, in that endothelial cells in rat, mouse, and human corneas cannot be readily stimulated to proliferate.

\section{Alterations in gene expression associated with eyelid opening}

As seen in Table 1, a number of gene products have been observed to be either up- or downregulated during the period of eyelid opening. These proteins can be roughly separated into four groups: (1) epithelial differentiation markers, (2) tear-film-associated proteins, (3) matrix components, and (4) cell-cycle-associated proteins. These proteins give clues to the important development processes that are altered around the time of eyelid opening. A recent report by Norman et al. (Norman et al., 2004) dramatically expanded this list. These authors used serial analysis of gene expression (SAGE) to compare adult and nine-day-old mouse cornea. Their findings suggest that only one-third of the expressed genes were common between the two groups, spectacularly supporting the concept that eyelid opening correlates with a major developmental step in the cornea.

\section{Epithelial differentiation markers}

Several proteins associated with epithelial differentiation have been observed to be either up- or downregulated in conjunction with eyelid opening. The expression and localization of these proteins can be roughly grouped into two categories. In the first group of proteins, which include $\alpha$-enolase (Chung et al., 1992), $\alpha 9$ integrin (Stepp et al., 1995), and EGF receptor (Zieske and Wasson, 1993), expression is seen in cells across the cornea at the time of birth (Figs. 6 and 7). During the period between birth and

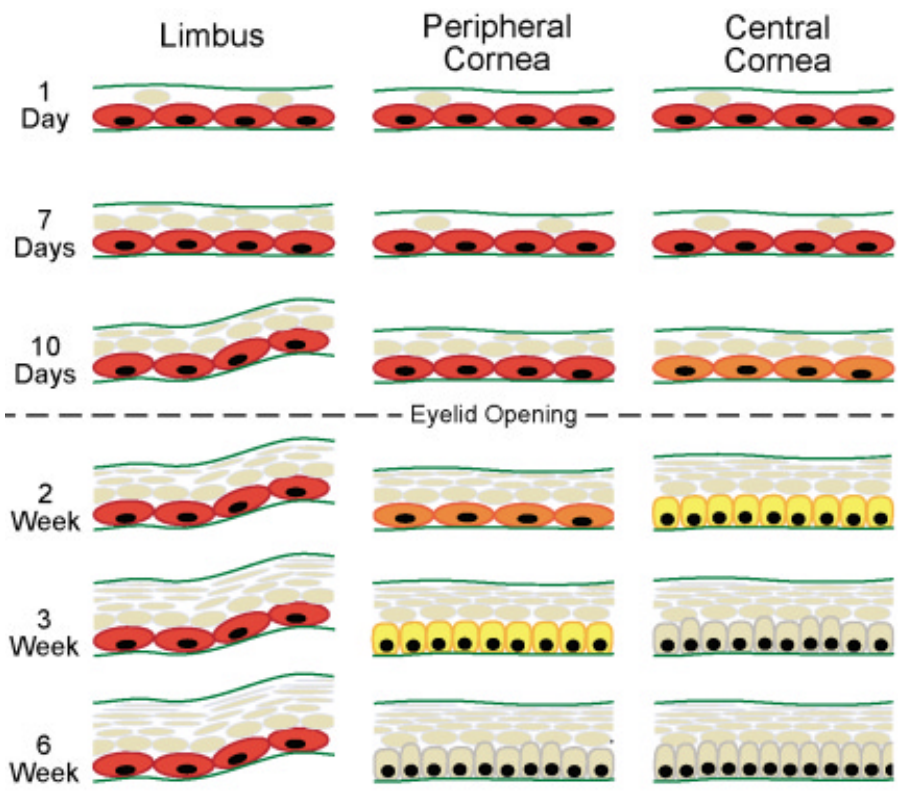

Fig. 6. Diagrammatic summary of changes in stratification, cell shape and expression of $\boldsymbol{\alpha}$-enolase during corneal development. All areas of the corneal epithelium, including central cornea, peripheral cornea, and limbus, expressed $\alpha$-enolase at high levels until ten days-of-age. At two weeks, change of cellular shape, epithelial stratification, and decreased expression of $\alpha$-enolase occurred at the central cornea, and basal cell shape changed from ovoid to cuboidal. Increased stratification of four-tofive layers of cells was seen concomitantly. At three weeks, basal cells in the peripheral cornea showed similar changes to those seen in the central cornea at two weeks. Also at three weeks, basal cells in the central cornea no longer expressed $\alpha$-enolase and began to change in shape from cuboidal to columnar. Basal cells in the limbus never changed their level of expression of $\alpha$-enolase or their ovoid shape. Note: the intensity of the shading in the basal cells indicates the level of expression of $\alpha$-enolase. (Adapted from Chung et al. (Chung et al., 1992) and reproduced courtesy of Investigative Ophthalmology and Visual Science.) 

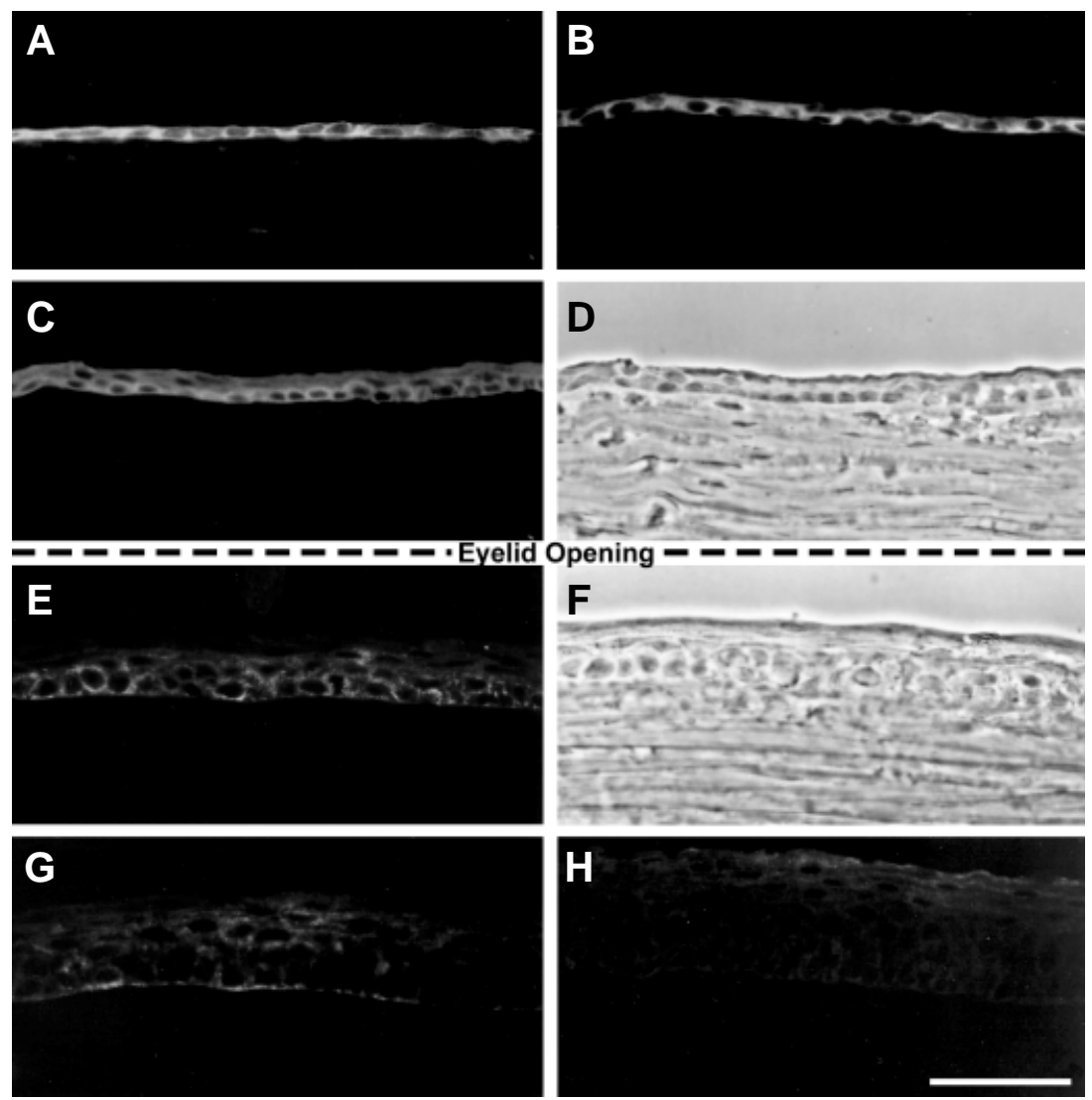

Fig. 7. Localization of $\alpha$-enolase in central cornea of developing rats. $\alpha$-Enolase was expressed at high levels in all basal cells in the corneal epithelium at one (A) and seven (B) days-of-age. At ten days (C), expression decreased in central cornea; (D) phase contrast of area shown in (C). At two weeks (E), expression was greatly reduced and cellular shape changed to cuboidal; (F) phase contrast of the area shown in (E). Basal cells in the central cornea no longer expressed $\alpha$-enolase after three weeks (G); six weeks (H). Bar, $50 \mu \mathrm{m}$. (Reproduced from Chung et al. (Chung et al., 1992), courtesy of Investigative Ophthalmology and Visual Science.)

eyelid opening, the expression of these proteins decreases in the central cornea and becomes increasingly restricted to the basal cell layer of the limbus. Within one-to-two weeks after eyelid opening, these proteins are localized in a pattern that they will maintain throughout adulthood. Furthermore, since they are concentrated in the limbal basal cell layer, which houses the corneal epithelial stem cells, they have been postulated to be markers of the corneal stem cells (Schermer et al., 1986; see Wolosin et al., (2004), for a more complete discussion of corneal stem cells.) It is not clear if these proteins are actual stem cell markers, but their localization pattern has lead to the hypothesis that, prior to eyelid opening, the epithelial cells in central cornea are stem cell-like, and that this property is lost in association with eyelid opening (Chung et al., 1992; Stepp et al., 1995; Zieske and Wasson, 1993).

In the second group of proteins, which includes keratins 3 (Chaloin-Dufau et al., 1990; Rodrigues et al., 1987) and 12 (Chaloin-Dufau et al., 1990; Liu et al., 1993), transketolase (Sax et al., 2000), connexin 43 (Wolosin et al., 2002), and aldehyde dehydrogenase (Burton et al., 1999; Downes and Holmes, 1992; Kays and Piatigorsky, 1997), increased expression has been observed in conjunction with eyelid opening. These proteins exhibit a reciprocal localization with those in the first group, in that they are present at low levels at birth and increase as the epithelium stratifies and matures. Interestingly, these proteins are not expressed in the basal cell layer of the limbus. This finding has lead to the hypothesis that the limbal basal cells are the least-differentiated cells in the corneal epithelium, and that this cell layer comprises the stem cell population (Schermer et al., 1986). An intriguing but unanswered question is whether the same regulatory factors control these proteins.

\section{Tear-film-associated proteins}

A second major grouping of proteins that are induced during the period corresponding to eyelid opening are proteins that are either components of the tear film or associated with maintaining the tear film. Several of these proteins have been identified: mucin 4 (muc4) (Tei et al., 1999), $\alpha$ 2,3sialyltransferase (Uehara et al., 1995), and an ocular surface glycocalyx component (Watanabe et al., 1993) that may be muc16 (Argueso et al., 2003). In contrast to proteins that increase in expression as the epithelium differentiates (see above), the expression of the tear-film-associated mucins, muc4 and muc16, closely correlated with eyelid opening (Tei et al., 1999; Watanabe et al., 1993). Indeed, Watanabe et al. (Watanabe et al., 1993) observed that muc16 was not detected until one day after eyelid opening. These authors also observed that, in cases of asynchronous eyelid opening, the open eye expressed the glycocalyx component, while the closed eye did not, and that surgically opening the closed eyelid led to rapid expression of the tear-film-associated mucins. This report suggests that eyelid opening stimulates the expression of tear-film-associated proteins. However, it is not clear if the stimulus is light, oxygen, or another unknown stimulus.

\section{Matrix components}

The period between birth and eyelid opening has been observed to involve major changes in the architecture of the stroma in rabbit, mouse, and rat corneas (Fig. 1) (Chung et al., 1992; Cintron et al., 1983; Song et al., 2003). These changes are manifested as a swelling of the stroma prior to eyelid opening and a thinning after opening. This alteration is accompanied by a decrease in stromal cell density. The swelling and subsequent thinning appears to be related to the sulfation of the proteoglycan portion of the lumican-a major keratan sulfate proteoglycan of the cornea (Song et al., 2003). Sulfation occurs around the time of eyelid opening in the mouse and just subsequent to opening in the rabbit (Blochberger, Cornuet etal., 1992; Blochberger, Vergnes et al., 1992; Smelser and Ozanics, 1957; Song et al., 2003; Ying et al., 1997). Presumably, the synthesis of keratan sulfate leads to an increase in water absorption and consequent swelling of the cornea. Subsequently, the maturation of the endothelial cell layer leads to the pumping of water from the stroma and consequent 
TABLE 1

\section{PROTEINS ALTERED IN ASSOCIATION WITH EYELID OPENING}

\begin{tabular}{|c|c|}
\hline Proteins & References \\
\hline \multicolumn{2}{|l|}{ Epithelial differentiation markers } \\
\hline Aldehyde dehydrogenase (class 3 ) & $\begin{array}{l}\text { (Burton et al., 1999; Downes and Holmes, } \\
\text { 1992; Kays and Piatigorsky, 1997) }\end{array}$ \\
\hline$\alpha$-enolase & (Chung et al., 1992) \\
\hline$\alpha 9$ integrin & (Stepp et al., 1995) \\
\hline Connexin 43 & (Wolosin et al., 2002) \\
\hline Epidermal growth factor receptor & (Zieske and Wasson, 1993) \\
\hline Keratin 3 & $\begin{array}{l}\text { (Chaloin-Dufau et al., 1990; } \\
\text { Rodrigues et al., 1987) }\end{array}$ \\
\hline Keratin 12 & (Chaloin-Dufau et al., 1990; Liu et al., 1993) \\
\hline Transketolase & (Sax et al., 2000) \\
\hline \multicolumn{2}{|l|}{ Tear-film-associated proteins } \\
\hline$\alpha$ 2,3-sialyltransferase & (Uehara et al., 1995) \\
\hline Mucin 4 & (Tei et al., 1999) \\
\hline Rat ocular surface glycocalyx protein & (Watanabe et al., 1993) \\
\hline \multicolumn{2}{|c|}{ Matrix components } \\
\hline Keratan sulfate proteoglycan & $\begin{array}{l}\text { (Blochberger, Cornuet et al., 1992; } \\
\text { Blochberger, Vergnes et al., 1992; } \\
\text { Smelser and Ozanics, 1957; } \\
\text { Song et al., 2003; Ying et al., 1997) }\end{array}$ \\
\hline Lumican & (Song et al., 2003) \\
\hline Tenascin C & (Maseruka et al., 2000) \\
\hline Type XII collagen (long form) & (Anderson et al., 2000) \\
\hline \multicolumn{2}{|l|}{ Cell cycle associated proteins } \\
\hline E2F1 & (Francesconi et al., 2000) \\
\hline p27 & (Joyce et al., 1998) \\
\hline p107 & (Francesconi et al., 2000) \\
\hline p130 & (Francesconi et al., 2000) \\
\hline \multicolumn{2}{|l|}{ Others } \\
\hline Glutathione peroxidase 1 & (Fujii et al., 2003) \\
\hline Calcitonin gene-related peptide & (Jones and Marfurt, 1991) \\
\hline
\end{tabular}

thinning of the cornea. This process appears to be important in the development of corneal clarity. Studies of lumican-deficient mice support the importance of this proteoglycan (Song et al., 2003). In these mice, the cornea does not swell around the time of eyelid opening, and the corneas have an elevated level of light scattering. Other matrix materials are also altered around the time of eyelid opening, but the role of these components is less clear.

\section{Cell-cycle-associated proteins}

As discussed in earlier sections of this review, major changes in the proliferative rate of cells in all three layers of the cornea occur around the time of eyelid opening. These changes include increased proliferation of the epithelium and decreased proliferation of the endothelium and stroma. The proliferative rates appear to correlate with alterations in the expression of cell cycle inhibitors, members of the retinoblastoma family, and members of the E2F family of transcription factors. The increase in epithelial proliferation corresponds with the increased level of stratification that occurs during this period. It is usually assumed that decreased proliferation of the endothelial cell layer is necessary to maintain a monolayer of cells that provide optimal fluid transport. It is less clear why the stromal cells become non-proliferative, but one explanation is that this allows the architecture of the stroma to remain stable - enabling the tissue to maintain transparency.

\section{Regulation of gene expression associated with eyelid opening}

Although an increasing amount of information is available about the events associated with eyelid opening, as well as alterations in gene expression, the regulation of these events is still poorly understood. Several recent articles have used molecular biological techniques to examine factors potentially involved in corneal development. Certainly, one of the key regulators of corneal and eye development is the transcription factor Pax6-mice lacking Pax6 do not form eyes. Davis et al. (Davis et al., 2003) have also demonstrated that Pax6 plays an essential role in corneal development by examining the Pax6 heterogeneous SEY mouse. They found that the corneal epithelium did not stratify to its normal thickness in these mice, and that cell-cell, as well as, cell-matrix adherence was compromised. Their data suggest that Pax6 is necessary for epithelial stratification; however, it is unclear if an environmental cue is required to stimulate the action of Pax6 in association with eyelid opening. Other factors that have been demonstrated to be involved in corneal development are TGF- $\beta 1$ (Flugel-Koch et al., 2002), notch1 (Nicolas et al., 2003), TGF- $\alpha$ (Reneker et al., 2000), the forkhead/winged-helix gene (Kidson et al., 1999), and IKB kinase $\alpha$ (Yoshida etal., 2000). Intriguingly, both overexpression of TGF- $\alpha$ and deletion of forkhead lead to the lack of an endothelial cell layer. However, in the first case, the epithelial layer is thinned, while in the second, the epithelium is thickened.

In addition to molecular factors, it is likely that alteration in the cornea's environment during eyelid opening plays a role in differential gene expression. Potential environmental cues include changes in light and oxygen. To examine the potential role of light in the expression of the epithelial differentiation marker transketolase, Sax et al. (Sax et al., 2000) compared mice reared in the dark to their normal littermates. They observed that the level of transketolase mRNA was two-fold lower in the dark-raised mice, indicating that light was a stimulus. However, the darkreared mice still exhibited a significant increase in transketolase message levels upon eyelid opening, indicating that light was not the only cue. This is supported by findings in human corneas, which open before birth. These corneas exhibit the same type of changes in epithelial differentiation and expression of differentiation markers as in species where the eyelids open after birth (Rodrigues et al., 1987). In another transgenic mouse study, Saika et al. (Saika et al., 2001) found that TGF $\beta-2$ knockout mice had a decreased accumulation of extracellular matrix materials and developed a thin cornea. Thus, it appears that TGF $\beta-2$ is an important signaling molecule, but its stimulus remains unknown.

In summary, the development of the cornea associated with eyelid opening involves many intriguing processes that are vital for the maturation of a light transparent cornea; however, many questions remain about how these processes are regulated. Several molecular factors have been identified that play a role in corneal development; however, their role during eyelid opening and the effect of environmental cues still await elucidation.

\section{References}

ANDERSON, S., SUNDARRAJ, S., FITE, D., WESSEL, H. and SUNDARRAJ, N. (2000). Developmentally regulated appearance of spliced variants of type XII collagen in the cornea. Invest Ophthalmol Vis Sci41:55-63. 
ARGUESO, P., SPURR-MICHAUD, S., RUSSO, C. L., TISDALE, A. and GIPSON, I. K. (2003). MUC16 mucin is expressed by the human ocular surface epithelia and carries the $\mathrm{H} 185$ carbohydrate epitope. Invest Ophthalmol Vis Sci44:24872495

BAHN, C. F., GLASSMAN, R. M., MACCALLUM, D. K., LILLIE, J. H., MEYER, R. F., ROBINSON, B. J. and RICH, N. M. (1986). Postnatal development of corneal endothelium. Invest Ophthalmol Vis Sci27:44-51.

BARISHAK, R. Y. Embryology of the Eye and Its Adnexa. 2nd, revised edition ed. Basel, Switzerland: Karger; 2001.

BEARDMORE, J. M. and RICHARDS, R. C. (1983). Concentrations of epidermal growth factor in mouse milk throughout lactation. J Endocrino/96:287-292.

BEEBE, D. C. and MASTERS, B. R. (1996). Cell lineage and the differentiation of corneal epithelial cells. Invest Ophthalmol Vis Sci37:1815-1825.

BLOCHBERGER, T. C., CORNUET, P. K. and HASSELL, J. R. (1992). Isolation and partial characterization of lumican and decorin from adult chicken corneas. A keratan sulfate-containing isoform of decorin is developmentally regulated. $J$ Biol Chem 267:20613-20619.

BLOCHBERGER, T. C., VERGNES, J. P., HEMPEL, J. and HASSELL, J. R. (1992). cDNA to chick lumican (corneal keratan sulfate proteoglycan) reveals homology to the small interstitial proteoglycan gene family and expression in muscle and intestine. J Biol Chem 267:347-352.

BURTON, M., REISDORPH, R., PROUGH, R. and LINDAHL, R. (1999). Modulation of class 3 aldehyde dehydrogenase gene expression. An eye opening experience. Adv Exp Med Bio/463:165-170.

CHALOIN-DUFAU, C., SUN, T. T. and DHOUAILLY, D. (1990). Appearance of the keratin pair K3/K12 during embryonic and adult corneal epithelial differentiation in the chick and in the rabbit. Cel/ Differ Dev 32:97-108.

CHUNG, E. H., BUKUSOGLU, G. and ZIESKE, J. D. (1992). Localization of corneal epithelial stem cells in the developing rat. Invest Ophthalmol Vis Sci33:21992206.

CINTRON, C., COVINGTON, H. and KUBLIN, C. L. (1983). Morphogenesis of rabbit corneal stroma. Invest Ophthalmol Vis Sci24:543-556.

CINTRON, C., COVINGTON, H. I., KUBLIN, C. L. and COVINGTON, H. (1988). Morphogenesis of rabbit corneal endothelium. Curr Eye Res 7:913-929.

DAVIS, J., DUNCAN, M. K., ROBISON, W. G., JR. and PIATIGORSKY, J. (2003). Requirement for Pax6 in corneal morphogenesis: a role in adhesion. $J \mathrm{Cell} \mathrm{Sc}$ 116:2157-2167.

DOWNES, J. and HOLMES, R. (1992). Development of aldehyde dehydrogenase and alcohol dehydrogenase in mouse eye: evidence for light-induced changes. Biol Neonate 61:118-123.

FLUGEL-KOCH, C., OHLMANN, A., PIATIGORSKY, J. and TAMM, E. R. (2002). Disruption of anterior segment development by TGF-beta1 overexpression in the eyes of transgenic mice. Dev Dyn 225:111-125.

FRANCESCONI, C. M., HUTCHEON, A. E., CHUNG, E. H., DALBONE, A. C., JOYCE, N. C. and ZIESKE, J. D. (2000). Expression patterns of retinoblastoma and E2F family proteins during corneal development. Invest Ophthalmol Vis Sci 41:1054-1062.

FUJII, T., IKEDA, Y., YAMASHITA, H. and FUJII, J. (2003). Transient elevation of glutathione peroxidase 1 around the time of eyelid opening in the neonatal rat. J Ocul Pharmacol Ther 19:361-369.

HANNA, C. and O'BRIEN, J. E. (1960). Cell production and migration in the epithelial layer of the cornea. Arch Ophthalmo/64:536-539.

HANNA, C. and O'BRIEN, J. E. (1961). Thymidine-tritium labeling of the cellular elements of the corneal stroma. Arch Ophthalmo/66:362-365.

HAUSTEIN, J. (1983). On the ultrastructure of the developing and adult mouse corneal stroma. Anat Embryol (Berl) 168:291-305.

HAY, E. D. (1979). Development of the vertebrate cornea. Int Rev Cyto/63:263-322.

HOGAN, M. J., ALVARADO, J. A. and WEDELL, J. E. Histology of the Human Eye. Philadelphia: W.B Saunders Co.; 1971.

JAKOBIEC, F. A. and OZANICS, V. General topographic anatomy of the eye. In: Jakobiec FA, e., ed. Ocular Anatomy, Embryology and Teratology. Philadelphia: Harper \& Row; 1982:1-9.

JONES, M. A. and MARFURT, C. F. (1991). Calcitonin gene-related peptide and corneal innervation: a developmental study in the rat. J Comp Neuro/313:132150.
JOYCE, N. C. (2003). Proliferative capacity of the corneal endothelium. Prog Retin Eye Res 22:359-389.

JOYCE, N. C., HARRIS, D. L. and MELLO, D. M. (2002). Mechanisms of mitotic inhibition in corneal endothelium: contact inhibition and TGF-beta2. Invest Ophthalmol Vis Sci43:2152-2159.

JOYCE, N. C., HARRIS, D. L. and ZIESKE, J. D. (1998). Mitotic inhibition of corneal endothelium in neonatal rats. Invest Ophthalmol Vis Sci39:2572-2583.

JOYCE, N. C., MEKLIR, B., JOYCE, S. J. and ZIESKE, J. D. (1996). Cell cycle protein expression and proliferative status in human corneal cells. Invest Ophthalmol Vis Sci37:645-655.

KAYS, W. T. and PIATIGORSKY, J. (1997). Aldehyde dehydrogenase class 3 expression: identification of a cornea-preferred gene promoter in transgenic mice. Proc Natl Acad Sci USA 94:13594-13599.

KIDSON, S. H., KUME, T., DENG, K., WINFREY, V. and HOGAN, B. L. (1999). The forkhead/winged-helix gene, Mf1, is necessary for the normal development of the cornea and formation of the anterior chamber in the mouse eye. Dev Biol 211:306-322.

LEE, H. T. and KAY, E. P. (2003). Regulatory role of PI 3-kinase on expression of Cdk4 and p27, nuclear localization of Cdk4, and phosphorylation of p27 in corneal endothelial cells. Invest Ophthalmol Vis Sci44:1521-1528.

LIU, C. Y., ZHU, G., WESTERHAUSEN-LARSON, A., CONVERSE, R., KAO, C. W., SUN, T. T. and KAO, W. W. (1993). Cornea-specific expression of K12 keratin during mouse development. Curr Eye Res 12:963-974.

MASERUKA, H., RIDGWAY, A., TULLO, A. and BONSHEK, R. (2000). Developmental changes in patterns of expression of tenascin- $C$ variants in the human cornea. Invest Ophthalmol Vis Sci 41:4101-4107.

MAURICE, D. M. The cornea and the sclera. London: Academic Press; 1985.

MURPHY, C., ALVARADO, J., JUSTER, R. and MAGLIO, M. (1984). Prenatal and postnatal cellularity of the human corneal endothelium. A quantitative histologic study. Invest Ophthalmol Vis Sci25:312-322.

NICOLAS, M., WOLFER, A., RAJ, K., KUMMER, J. A., MILL, P., VAN NOORT, M., HUI, C. C., CLEVERS, H., DOTTO, G. P. and RADTKE, F. (2003). Notch1 functions as a tumor suppressor in mouse skin. Nat Genet 33:416-421.

NORMAN, B., DAVIS, J. and PIATIGORSKY, J. (2004). Postnatal gene expression in the normal mouse cornea by SAGE. Invest Ophthalmol Vis Sci45:429-440.

RENEKER, L. W., SILVERSIDES, D. W., XU, L. and OVERBEEK, P. A. (2000) Formation of corneal endothelium is essential for anterior segment development - a transgenic mouse model of anterior segment dysgenesis. Development 127:533-542.

RODRIGUES, M., BEN-ZVI, A., KRACHMER, J., SCHERMER, A. and SUN, T. T. (1987). Suprabasal expression of a 64-kilodalton keratin (no. 3) in developing human corneal epithelium. Differentiation 34:60-67.

SAIKA, S., LIU, C. Y., AZHAR, M., SANFORD, L. P., DOETSCHMAN, T., GENDRON, R. L., KAO, C. W. and KAO, W. W. (2001). TGFbeta2 in corneal morphogenesis during mouse embryonic development. Dev Bio/240:419-432.

SAX, C. M., KAYS, W. T., SALAMON, C., CHERVENAK, M. M., XU, Y. S. and PIATIGORSKY, J. (2000). Transketolase gene expression in the cornea is influenced by environmental factors and developmentally controlled events. Cornea 19:833-841.

SCHERMER, A., GALVIN, S. and SUN, T. T. (1986). Differentiation-related expression of a major $64 \mathrm{~K}$ corneal keratin in vivoand in culture suggests limbal location of corneal epithelial stem cells. J Cell Biol103:49-62.

SCHONTHAL, A. H., HWANG, J. J., STEVENSON, D. and TROUSDALE, M. D. (1999). Expression and activity of cell cycle-regulatory proteins in normal and transformed corneal endothelial cells. Exp Eye Res 68:531-539.

SEVEL, D. and ISAACS, R. (1988). A re-evaluation of corneal development. Trans Am Ophthalmol Soc 86:178-207.

SMELSER, G. K. and OZANICS, V. (1957). Distribution of radioactive sulfate in the developing eye. Am J Ophtha/mo/44:102-109; discussion 109-110.

SONG, J., LEE, Y. G., HOUSTON, J., PETROLL, W. M., CHAKRAVARTI, S., CAVANAGH, H. D. and JESTER, J. V. (2003). Neonatal corneal stromal development in the normal and lumican-deficient mouse. Invest Ophthalmol Vis Sci 44:548-557.

STEPP, M. A., ZHU, L., SHEPPARD, D. and CRANFILL, R. L. (1995). Localized distribution of alpha 9 integrin in the cornea and changes in expression during corneal epithelial cell differentiation. J Histochem Cytochem 43:353-362. 
TEI, M., MOCCIA, R. and GIPSON, I. K. (1999). Developmental expression of mucin genes ASGP (rMuc4) and rMuc5ac by the rat ocular surface epithelium. Invest Ophthalmol Vis Sci40:1944-1951.

THULESEN, J., NEXO, E., RAABERG, L. and POULSEN, S. S. (1994). Decreased level of epidermal growth factor in milk from diabetic rats. Pediatr Res 35:107-111.

TSUTSUMI, O., TSUTSUMI, A. and OKA, T. (1987). A possible physiological role of milk epidermal growth factor in neonatal eyelid opening. Am J Physiol 252:R376-379.

UEHARA, F., OZAWA, M., IWAKIRI, N. and OHBA, N. (1995). Expression of distribution of alpha 2,3-sialyltransferase mRNA in rat cornea. Jpn J Ophthalmol 39:30-34.

WATANABE, H., TISDALE, A. S. and GIPSON, I. K. (1993). Eyelid opening induces expression of a glycocalyx glycoprotein of rat ocular surface epithelium. Invest Ophthalmol Vis Sci34:327-338.

WOLOSIN, J.M., BUDAK, M.T. and AKINCI, M.A.M. (2004). Ocular surface epithelial and stem cell development. Int. J. Dev. Biol. 48: 971-991.
WOLOSIN, J. M., SCHUTTE, M., ZIESKE, J. D. and BUDAK, M. T. (2002). Changes in connexin43 in early ocular surface development. Curr Eye Res 24:430-438.

XIE, W., CHOW, L. T., PATERSON, A. J., CHIN, E. and KUDLOW, J. E. (1999). Conditional expression of the ErbB2 oncogene elicits reversible hyperplasia in stratified epithelia and up-regulation of TGFalpha expression in transgenic mice. Oncogene 18:3593-3607.

YING, S., SHIRAISHI, A., KAO, C. W., CONVERSE, R. L., FUNDERBURGH, J. L., SWIERGIEL, J., ROTH, M. R., CONRAD, G. W. and KAO, W. W. (1997) Characterization and expression of the mouse lumican gene. $J$ Biol Chem 272:30306-30313.

YOSHIDA, K., HU, Y. and KARIN, M. (2000). IkappaB kinase alpha is essential for development of the mammalian cornea and conjunctiva. Invest Ophthalmol Vis Sci41:3665-3669.

ZIESKE, J. D., GUIMARAES, S. R. and HUTCHEON, A. E. (2001). Kinetics of keratocyte proliferation in response to epithelial debridement. Exp Eye Res 72:33-39.

ZIESKE, J. D. and WASSON, M. (1993). Regional variation in distribution of EGF receptor in developing and adult corneal epithelium. J Cel/ Sci106:145-152. 